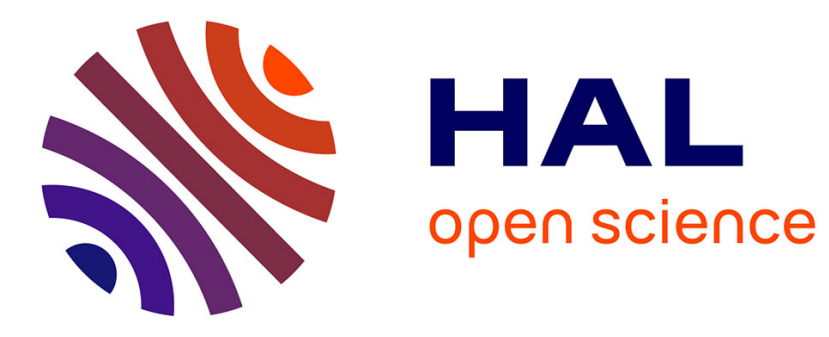

\title{
Rapid Prototyping: energy and environment in the spotlight
}

\author{
Pascal Mognol, Denis Lepicart, Nicolas Perry
}

\section{To cite this version:}

Pascal Mognol, Denis Lepicart, Nicolas Perry. Rapid Prototyping: energy and environment in the spotlight. Rapid Prototyping Journal, 2006, 12 (1), pp.26-34. 10.1108/13552540610637246 . hal00476639

\section{HAL Id: hal-00476639 \\ https://hal.science/hal-00476639}

Submitted on 2 Feb 2014

HAL is a multi-disciplinary open access archive for the deposit and dissemination of scientific research documents, whether they are published or not. The documents may come from teaching and research institutions in France or abroad, or from public or private research centers.
L'archive ouverte pluridisciplinaire HAL, est destinée au dépôt et à la diffusion de documents scientifiques de niveau recherche, publiés ou non, émanant des établissements d'enseignement et de recherche français ou étrangers, des laboratoires publics ou privés. 


\title{
Rapid Prototyping: energy and environment in the
}

\section{spotlight}

\author{
Pascal MOGNOL, Denis LEPICART, Nicolas PERRY \\ IRRCYN, 1 rue de la Noé BP 92101 F44321 Nantes cedex 03, FRANCE \\ Email: mognol@bretagne.ens-cachan.fr
}

\section{Research paper}

The authors

Pascal MOGNOL (Associate Professor in the Modelisation Optimisation Process Production team), Denis LEPICART (Master degree student, Lecturer at Ecole Centrale de Lille) and Nicolas PERRY (Associate Professor in the Virtual Engineering for Industrial Engineering team) are based at the Communications and Cybernetic Research Institute of Nantes (IRCCYN), France.

\section{Purpose}

Integration of the Rapid Prototyping environmental aspects: first focus on the electrical energy consumption.

\section{Design/methodology/approach}

Various manufacturing parameters have been tested on three rapid prototyping systems: Thermojet (3DS), FDM 3000 (Stratasys) and EOSINT M250 Xtended (EOS). The objective is to select sets of parameters for reduction of electrical energy consumption. For this, we have manufactured a part in several orientations and positions in the chamber of these RP systems. For each test, we noted the electrical 
power. Finally, we propose certain rules to minimize this electrical energy consumption during a job.

\section{Findings}

It is important to minimize the manufacturing time but there is no general rule for optimization of electrical energy consumption. Each RP system must be tested with energy consumption considerations under the spotlight.

\section{Research limitations/implications}

Our work is only based on Rapid Prototyping processes. Our objective is to take into consideration the complete life-cycle of an rapid prototyped part: manufacturing of raw material as far as reprocessing of waste.

\section{Practical implications}

To decrease electrical energy consumption for a job

\section{What is original/value of paper}

The environmental aspects are not studied as well as in rapid prototyping. Keywords: Environment, energy, electrical power, Rapid prototyping

\section{Introduction}

During the 20th century, environmental considerations aren't taken into account in the life-cycle of a product. Now, under the politic and consumer pressure, environmental laws have appeared, the standard ISO 14000 is used by many industries. Valorising scraps is a new argument for advertising and communication. 
The number of ISO 14000 certificates has increased the last twenty years and now, more than 40000 industries are certified worldwide (only 257 in December 95). The Product Life Management (PLM) is applied during the conception and the manufacturing of products.

Rich countries have studied the major factor of pollution: the production of energy (Efthimeros 2000). One solution consists to develop a clean form of energy and to decrease consumption. For this, the alternative production of energy (wind turbine, solar system) is used more often and the productions systems are increasingly well mastered with regards to energy. But energy production is continuously increasing and rejecting $\mathrm{CO} 2$ emissions in the atmosphere. For example, French production of various energies is given figure 1 (Obs 2002).

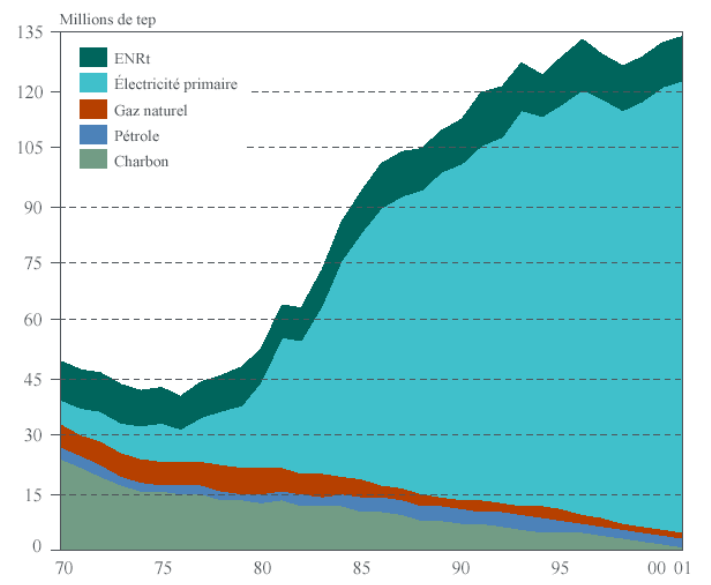

Figure 1 : production of energy during $1970-2001$

The program "JOULE III" has studied this emission for European community (IEST 2001). In the U.S.A, a similar program, managed by the U.S. Department of Energy (DOE), propose solutions to greatly reduce atmospheric emission of CO2 (Brown 2001). 
Factories have improved their production systems to have lower electrical energy consumption. In raw material processing, plastic injection or machining processes, electrical energy consumption is taken into consideration to select the best process (Kalitventzeff 2000; Munoz 1995). HYDRO MAGNESIUM, a company, which makes magnesium parts, has a factory in Porsgrunn (Norway). They have studied their process from the beginning to the end and they have proposes, at each state, solution to reduce emissions. They have observed during the last few years, a global diminution of $\mathrm{CO} 2$ emissions in their magnesium production, which put them in compliance with current environmental norms (Hydro 2000).

For the machining production, Srinavasan (Srinivasan 1999) propose a method for integrating an "environmental factor" in process planning. The cutting parameters and tools paths are optimized to reduce waste of different machining operations. His method is called "Micro planning " and " macro planning ".

A multi-criteria analysis is developed by Pun (Pun 2003) to evaluate waste of plastic production. The analysis is based on survey realized with 22 plastic injection factories.

The environmental problem is beginning to take into account to determine a process of a mass production. For the Rapid Prototyping, waste and environmental aspects are not now well respected. Nevertheless, raw material (powder with nickel for example), process (consumption of 
energy) and product (post treatment, rejection) have an impact for environmental aspect.

In this paper, we present our research based on consumption of electrical energy for three rapid prototyping systems : Stratasys FDM 3000, 3DS Thermojet and EOS EOSINT M250 Xtended.

3DS and Stratasys are the leaders on the 2002 market for 3D printer with a total about 1600 systems (Wohlers 2003). The EOS system is representative of SLS machine used to manufacture Rapid Tooling.

\section{Protocol of tests}

For each system, we have measured electrical power when machines are on "stand by" and "in work". We have also studied the influence of machine parameters for the manufacturing of a part. These parameters are listed below:

- Orientation, position and height of the part,

- Thickness of the layers and manufacturing strategies,

- Design and quantity of support generated,

- Manufacturing time.

We have defined a part for these tests: it is a part with three unequal length orthogonal branches (figure 2). Like this, the different orientations of the part generate more or less quantity of support. The different 
positions allow having a $Z$ axis construction with different values: 20,30 or $40 \mathrm{~mm}$.
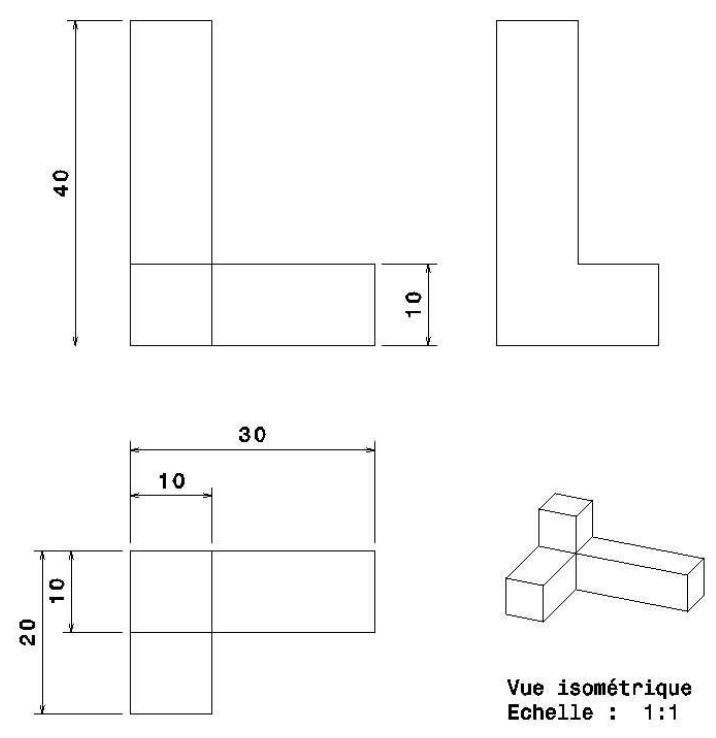

Figure 2 : part definition

We propose 18 positions for the manufacturing of the part. Each position is suitable for testing the parameters and for having information about the manufacturing time and the electrical energy consumption (figure 3).

These 9 positions create few volume of support. Position 10 to 18 is the same with an $\mathrm{Y} 180^{\circ}$ rotation. These positions create more support. For example, position " 16 " is represented figure 4. 


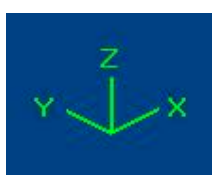

REPERE

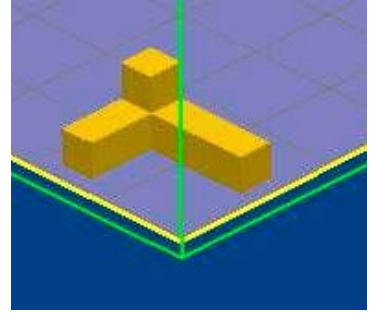

POSITION 1

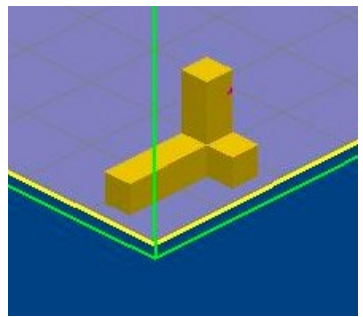

POSITION 4

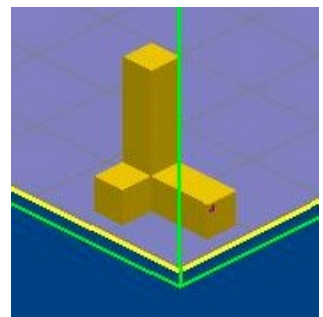

POSITION 7

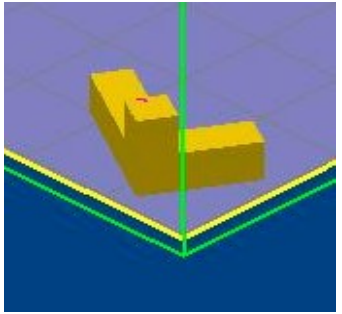

POSITION 2

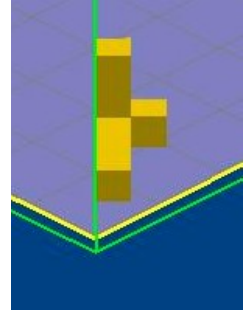

POSITION 5

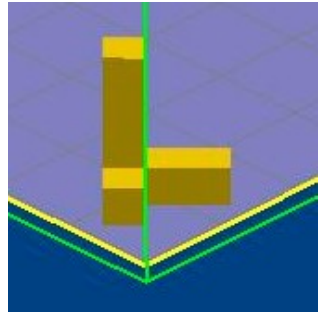

POSITION 8

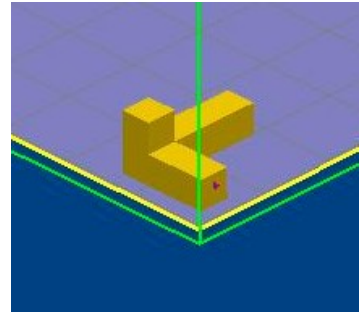

POSITION 3

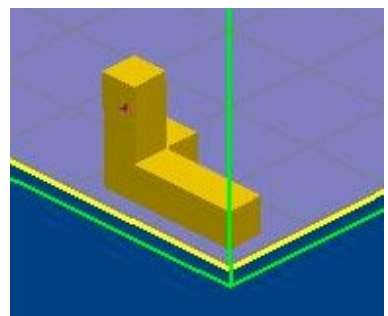

POSITION 6

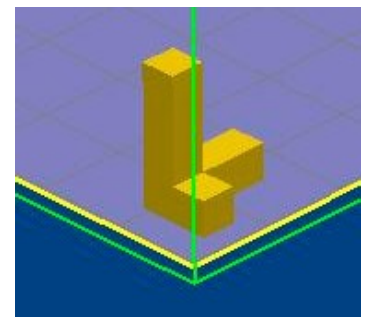

POSITION 9

Figure 3 : the various positions of the part.

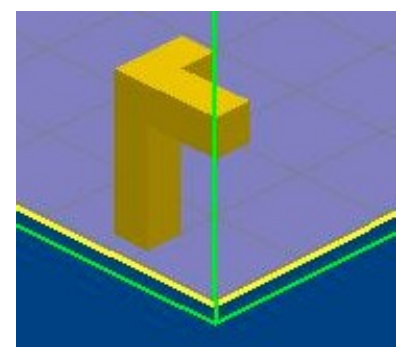

Figure 4: Position 16 


\section{Results and discussion}

\section{THERMOJET:}

\section{Electrical power for " stand by ":}
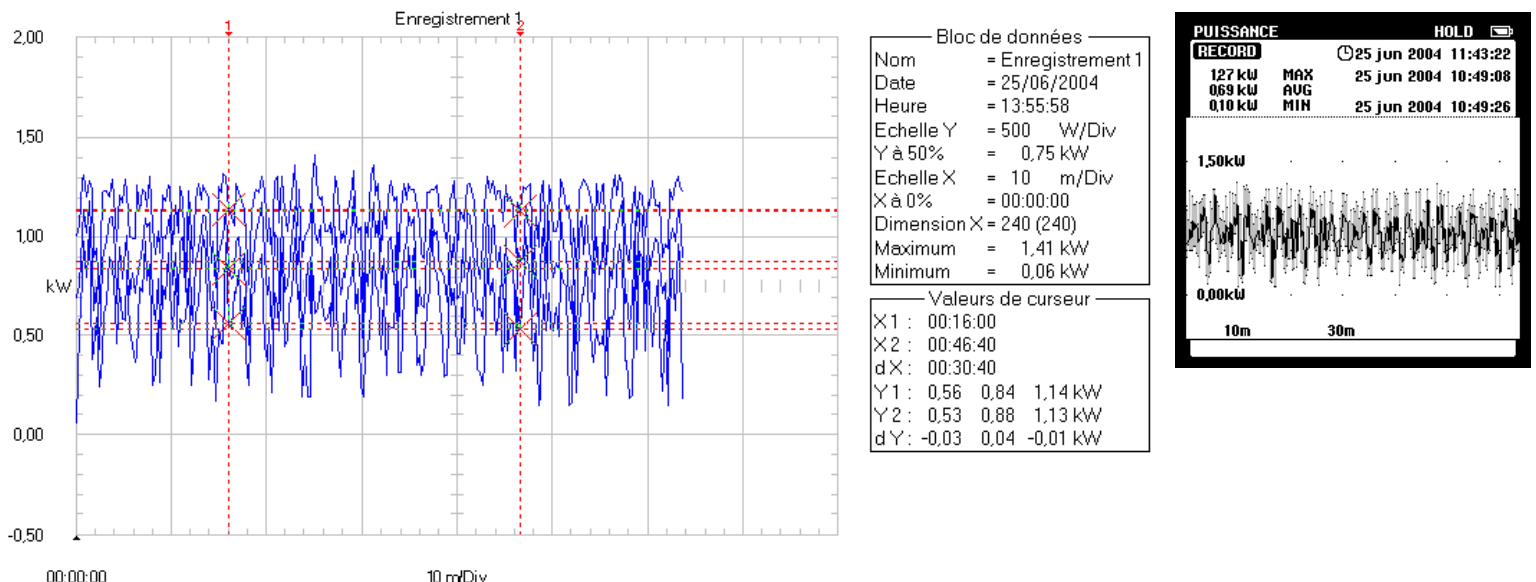

Figure 5 : Thermojet system, electrical power for « stand by »

There are 3 curves on Figure 5: Max, Min and average value. We can note that curves have some irregularities: It is due to the thermal cycle of the Thermojet, which continuously controls the temperature of wax.

On figure 5 , the average value is $\underline{0.69 \mathrm{~kW}}$.

\section{Electrical power for " in work":}
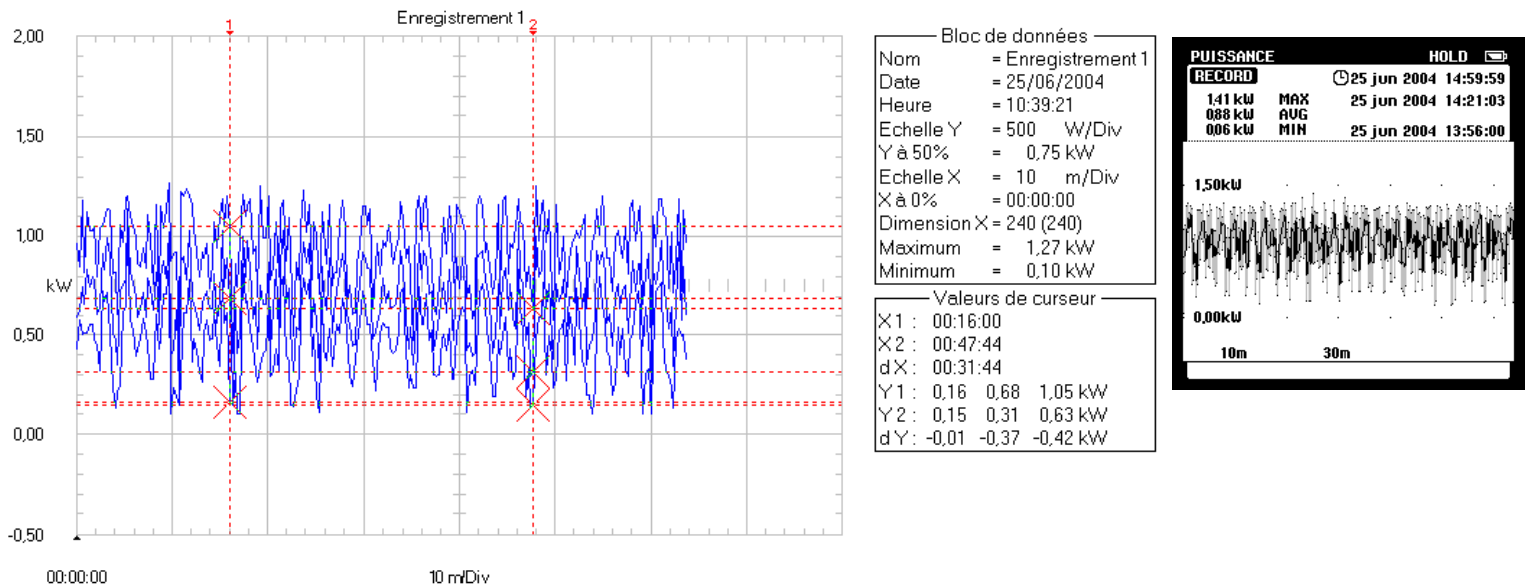

Figure 6: Thermojet system, electrical power for « in work »

The average value is $\underline{0.88 \mathrm{~kW}}$ (figure 6). The difference with the stand by power is $0,19 \mathrm{~kW}$ or $27,5 \%$. The difference is slight because the 
Thermojet keep the manufacturing chamber at a constant temperature during the stand by.

\section{Manufacturing of the part:}

The manufacturing time of each position is given table 1 :

\begin{tabular}{|c|c|c|c|}
\hline & $\begin{array}{c}\text { Manufacturing } \\
\text { time }\end{array}$ & $\%$ & $\begin{array}{c}\text { Electrical energy } \\
\text { consumption for } \\
\text { job }(\mathrm{kWh})\end{array}$ \\
\hline POSITION 1 & 2h20min43s & 0 & 2,1 \\
\hline POSITION 2 & 2h21min09s & 0,31 & 2,1 \\
\hline POSITION 3 & 2h21min22s & 0,46 & 2,1 \\
\hline POSITION 4 & 3h23min08s & 44,36 & 2,9 \\
\hline POSITION 5 & 3h23min23s & 44,53 & 2,9 \\
\hline POSITION 6 & 3h21min49s & 43,42 & 2,9 \\
\hline POSITION 7 & 4h18min55s & 84,00 & 3,8 \\
\hline POSITION 8 & 4h20min00s & 84,77 & 3,8 \\
\hline POSITION 9 & 4h19min35s & 84,47 & 3,8 \\
\hline POSITION 10 & 2h20min43s & 0 & 2,1 \\
\hline POSITION 11 & 2h21min09s & 0,31 & 2,1 \\
\hline POSITION 12 & 2h21min23s & 0,47 & 2,1 \\
\hline POSITION 13 & 3h23min09s & 44,37 & 2,9 \\
\hline POSITION 14 & 3h23min23s & 44,53 & 2,9 \\
\hline POSITION 15 & 3h21min49s & 43,42 & 2,9 \\
\hline POSITION 16 & 4h18min55s & 84,00 & 3,8 \\
\hline POSITION 17 & 4h20min00s & 84,77 & 3,8 \\
\hline POSITION 18 & 4h19min35s & 84,47 & 3,8 \\
\hline
\end{tabular}

Table 1 : Results for Thermojet system

The position of the part has a very minor effect on manufacturing time (see $1,2,3$ results and 4, 5, 6 results for example, table 1 ).

We can observe that the support does not increase time (see 1 and 10 results or 2 and 11 results). In fact, the deposit wax head have the same movement whatever the geometry of the layer of the part.

NB: The support increase consumption of raw material...

For the Thermojet, only the " $Z$ " height of the part is important for the manufacturing time and consequently, for energy consumption. 


\section{FDM:}

\section{Electrical power for " stand by ":}
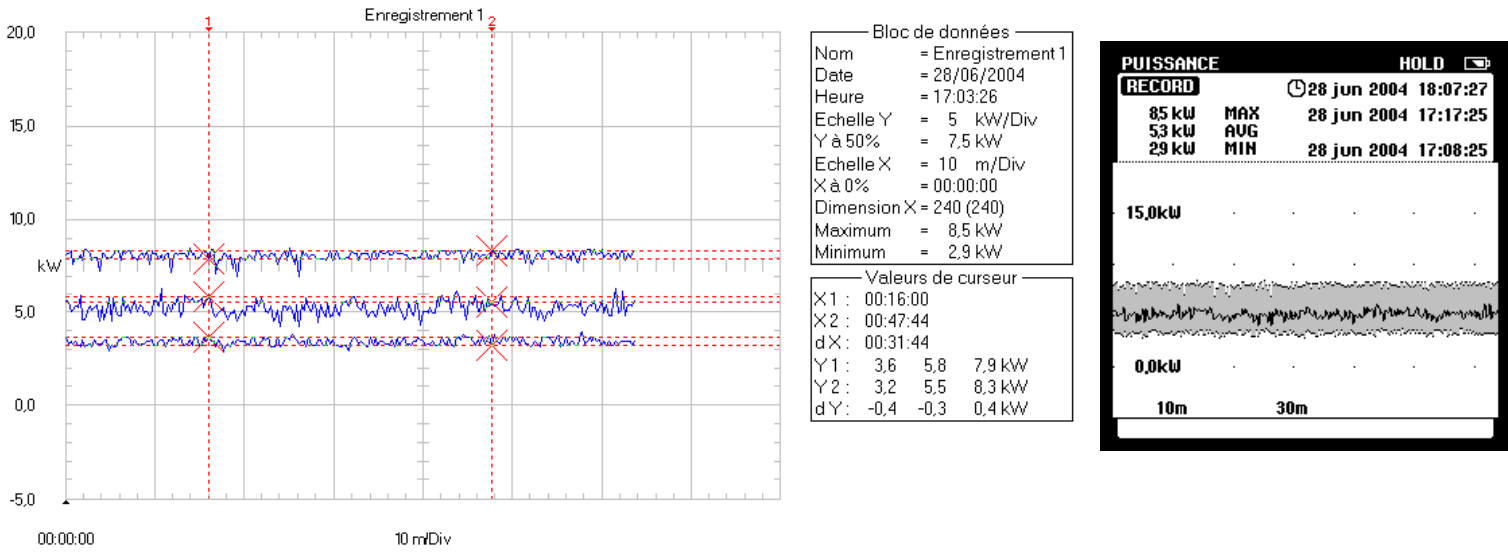

Figure 7 : FDM system, electrical power for « stand by »

The average value for "stand by " is given on figure 7 . We read 5,3 KW with a factor $\times 10$ (to increase accuracy of the curves). So, the electrical power is $0,53 \mathrm{~kW}$.

In figure 8 , we open the door of the FDM for $5 \mathrm{~s}$. We can observe a stop of heating system during the opening. After, the heating cycle is in progress up to $65^{\circ} \mathrm{C}$ and the temperature is stabilized over $65^{\circ} \mathrm{C}$..

In this case, the electrical power increases to $1,32 \mathrm{~kW}(+249 \%)$.

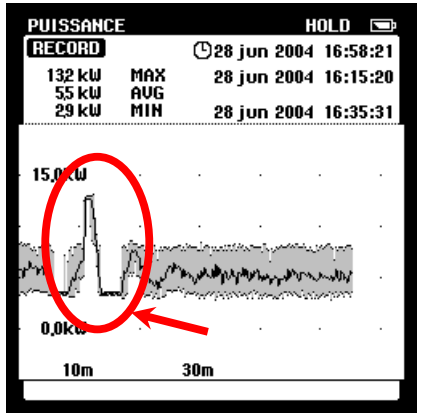

Figure 8 : electrical power (door open) 


\section{Electrical power for " in work":}
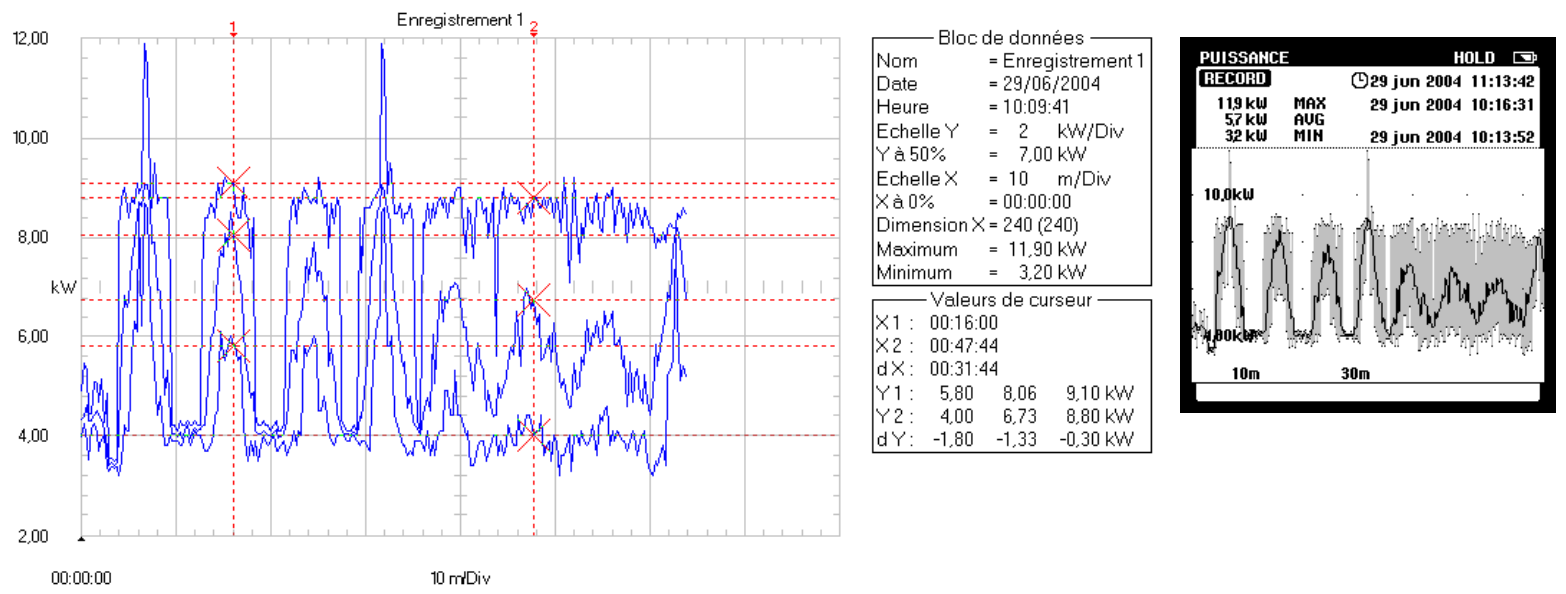

Figure 9 : FDM system, electrical power for « in work »

For each position of the part, we have obtained the same average

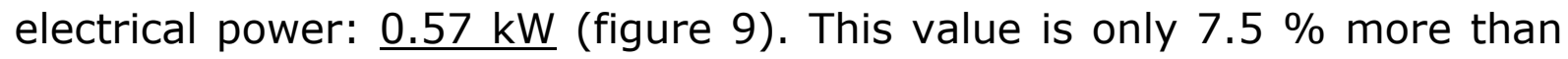
the "stand by" value. As mentioned for the Thermojet, the principal electrical power is due to the heating system of the machine. Motorizations and printer head have a minor effect on electrical power.

We have also tested the different strategies proposed by Stratasys to manufacture the part. The "solid double wide" strategy has exactly the same consumption. However, this strategy requires more raw material than the first strategy employed.

Supports of the parts are eliminated in a ultrasonic container which contain hot water $\left(70^{\circ} \mathrm{C}\right)$ with supplement. The electrical power is $0,5 \mathrm{~kW}$ (figure 10). 


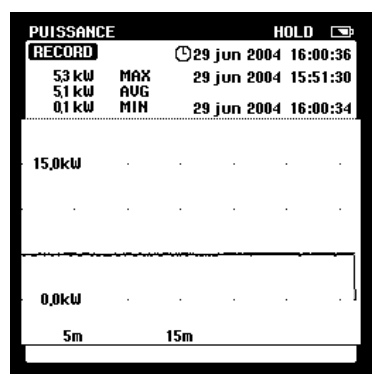

Figure 10: Ultrasonic container

Stratasys recommend to immerse part 8 hours in this container for cleaning all the support. Like this, the electrical energy consumption for cleaning a part is $4 \mathrm{kWh}$.

\section{Manufacturing of the part:}

We have also tested 18 positions to manufactured the proposed part (table 2):

\begin{tabular}{|c|c|c|c|c|c|c|c|}
\hline & $\begin{array}{l}\text { During } \\
\text { time of } \\
\text { the job } \\
\text { (min) }\end{array}$ & $\begin{array}{c}\text { Vol } \\
\text { d'ABS }^{\prime}\left(\mathrm{cm}^{3}\right)\end{array}$ & $\begin{array}{l}\text { Vol of } \\
\text { support } \\
\left(\mathrm{cm}^{3}\right)\end{array}$ & $\%$ (time) & $\begin{array}{l}\% \text { of } \\
\text { ABS }\end{array}$ & $\begin{array}{c}\% \text { of } \\
\text { support }\end{array}$ & $\begin{array}{c}\text { Electrical } \\
\text { energy } \\
\text { consumption } \\
\text { kWh } \\
\end{array}$ \\
\hline POSITION 1 & 56 & 7 & 0,59 & 3,70 & 92,23 & 7,77 & 0,5 \\
\hline POSITION 2 & 54 & 6,72 & 0,59 & 0,00 & 91,93 & 8,07 & 0,48 \\
\hline POSITION 3 & 56 & 7 & 0,59 & 3,70 & 92,23 & 7,77 & 0,5 \\
\hline POSITION 4 & 61 & 7,14 & 0,49 & 12,96 & 93,58 & 6,42 & 0,57 \\
\hline POSITION 5 & 60 & 6,9 & 0,49 & 11,11 & 93,37 & 6,63 & 0,56 \\
\hline POSITION 6 & 61 & 7,14 & 0,49 & 12,96 & 93,58 & 6,42 & 0,57 \\
\hline POSITION 7 & 65 & 7,05 & 0,41 & 20,37 & 94,50 & 5,50 & 0,6 \\
\hline POSITION 8 & 63 & 6,75 & 0,41 & 16,67 & 94,27 & 5,73 & 0,58 \\
\hline POSITION 9 & 65 & 7,05 & 0,41 & 20,37 & 94,50 & 5,50 & 0,6 \\
\hline POSITION 10 & 84 & 7,13 & 1,97 & 55,56 & 78,35 & 21,65 & 0,8 \\
\hline POSITION 11 & 82 & 6,93 & 1,93 & 51,85 & 78,22 & 21,78 & 0,78 \\
\hline POSITION 12 & 84 & 7,13 & 1,97 & 55,56 & 78,35 & 21,65 & 0,8 \\
\hline POSITION 13 & 111 & 7,14 & 2,61 & 105,56 & 73,23 & 26,77 & 1,05 \\
\hline POSITION 14 & 107 & 6,82 & 2,46 & 98,15 & 73,49 & 26,51 & 1,01 \\
\hline POSITION 15 & 109 & 7,14 & 2,41 & 101,85 & 74,76 & 25,24 & 1,03 \\
\hline POSITION 16 & 133 & 7,13 & 2,69 & 146,30 & 72,61 & 27,39 & 1,25 \\
\hline POSITION 17 & 130 & 6,85 & 2,62 & 140,74 & 72,33 & 27,67 & 1,22 \\
\hline POSITION 18 & 133 & 7,13 & 2,7 & 146,30 & 72,53 & 27,47 & 1,25 \\
\hline
\end{tabular}

Table 2 : Results for FDM system 
The part manufactured with the position 2 decreases the energy consumption over $3 \%$ against positions 1 and 3 .

It is due to the strategy of manufacture design by Stratasys: The computer calculates the longest diagonal of the part and begins the manufacture at this straight line. For the tested parts, these positions allow to obtain part a little more quickly (figure 11 ).

"take in figure $11 "$

The same phenomena are visible to position 5 (against positions 4 and 6), position 8 (against positions 7 and 9), position 11 (against positions 10 and 12), position 14 (against positions 13 and 15) and position 17 (against positions 16 and 18 ).

For the FDM, the height (along $Z$ axis) is not the principal parameter of the electrical energy consumption, it increase only to $20 \%$ (See position 1 against position 7, the part is build without support). The support is the major parameter, the manufacturing time (and the electrical energy consumption) increase to $108 \%$ (See position 9 against position 18).

\section{EOS :}

\section{Electrical power for " stand by ":}

The LASER is kept at a constant temperature $\left(20^{\circ} \mathrm{C}\right)$. Each peak is corresponding with each run of cooler unit (figure 12).

The average electrical power, including these peaks is $\underline{2 \mathrm{~kW}}$.

"take in figure $12 "$ 


\section{Electrical power for " in work":}

"take in figure $13 "$

When a part is manufactured, the electrical power increased consequentially. The average electrical power increase is $4 \mathrm{~kW}$ (average for 4 hours of manufacturing) (figure 13). This increase is due to the LASER and its cooler unit.

\section{Manufacturing of the part:}

These results are similar to the Thermojet results. The principal parameter is the height of the manufactured part (table 3).

\section{"take in table 3"}

We can also note that supports have not a lot of influence on electrical energy consumption (only $4 \%$ more, see positions 4 and 13 , or 7 and 16).

There is absolutely no difference between the positions 1,2 and 3 (id for 4,5 and 6 , etc..), only $Z$ axis positioning is important.

These results are essentially due to the conception of the machine: the speed of the LASER displacement is $300 \mathrm{~mm} / \mathrm{s}$ and there are 22 seconds of waiting between 2 layers (time to prepare the following layer with the scraper). So the manufacturing time is decomposed in a long waiting time and a short laser sintering time. 
For the same reason, the different strategies proposed by EOS have no influence on the electrical energy consumption. For example, table 4 give us a result for a part manufactured in position 1 with another strategy. There is only $1 \%$ difference.

"take in table 4"

\section{Conclusion}

The following table 5 summarises the influence of the various parameters for each rapid prototyping system. We have classified this influence in 3 levels: no influence, moderate influence and big influence:

"take in table 5"

The manufacturing time is the most important parameter because the electrical power of each rapid prototyping system is approximately constant during the job. In fact, the electrical energy consumption is directly dependent with the duration of the job.

To minimize the electrical energy consumption, manufacturing time must be minimized. This one is a function of different parameters:

- For the Thermojet and EOS, the height of the part must be minimized,

- For the FDM, it is the volume of support which be minimized. 
The following table 6 gives electrical power and electrical energy consumption when Rapid Prototyping systems are on "stand by" and "in work".

"take in table 6"

We can observe, for the tested part, an important difference of consumption between the minimum and the maximum (up to a factor 2,6 for FDM and 1,75 for EOS).

With good set of parameters, it is possible to save $45 \%$ of electrical energy for the Thermojet, $61 \%$ for the FDM and $43 \%$ for the EOS.

This study is based only on the process. The following work is on the manufacture of raw material and the reprocessing of rejects of these rapid prototyping systems:

- What is the environmental effect of the manufacturing of powder for RP systems?

- How are used parts reprocessed?

- And finally what is the global impact for environment for a complete Rapid prototyped part?

\section{references}


M. A. Brown, M. D. Levine, W. Short, J. G. Koomey, "Scenarios for a clean energy future", Energy Policy 29 (2001) pages 1179-1196.

G. A. Efthimeros, D. T. Tsahalis, "Intensified energy-saving technologies developed in EU-funded research: a review ", Applied Thermal Engineering 20 (2000), pages 1607-1613.

IEST, "EXSYS II : An expert system for optimal insertion of intensified energy saving technologies (IEST) in the industrial processes", final publishable report, 2001.

HYDRO MAGNESIUM. " Life Cycle Environmental Data for Production of Magnesium Die castings ". technical report, 2000 http://www.hydromagnesium.com/

B. Kalitventzeff, F. Maechal, "Optimal insertion of energy saving technologies in industrial processes: a web-based tool helps in developments and co-ordination of a European R\&D project ", Applied Thermal Engineering 20 (2000), pages 1347-1364.

A.A. Munoz, P. Sheng, "An analytical approach for determining the environmental impact of machining processes", Journal of Materials Processing Technology 53 (1995) pages 736-758. 
Observatoire de l'énergie, "L'énergie en France - repères", rapport, édition 2002.

Kit-Fai Pun, Ip-Kee Hui, Winston G. Lewis, Henry C. W. Lau, "A multiplecriteria environmental impact assessment for the plastic injection molding process: a methodology", Journal of Cleaner Production 11 (2003) pages 41-49.

M. Srinivasan, P. Sheng, "Feature-based process planning for environmentally concious machining", Robotics and Computer Integrated Manufacturing 15 (1999) pages 257-281.

T. Wohlers "Wohlers report 2003", Wohlers associates, 2003 